\title{
The Differences of the Student Learning Outcome Using Realistic Mathematics Learning Approaches (PMR) And Contextual Learning Approaches (CTL) on the Sets Material
}

\author{
${ }^{1}$ Nurina Kurniasari Rahmawati, ${ }^{2}$ Amah \\ ${ }^{1,2}$ STKIP Kusumanegara, Jakarta Timur \\ ${ }^{1}$ Correspondence Address; Arie_pk@stkipkusumanegara.ac.id
}

\begin{abstract}
This research aims to determine differences in learning outcomes of students who use Realistic Mathematics Learning (PMR) and Contextual Approach (CTL) approaches on the set Material. This research method is quasi experiment with posttest only control design. The sampling technique was used cluster random sampling with 2 experimental classes These are experimental class 1 (the class was treated with the Realistic Mathematics Education (PMR) approach and experimental class 2 (the class was treated with the Contextual Learning (CTL) approach The hypothesis test is used the t-test. The results of the research is found that there were differences between the student learning outcome in the set material using Realistic Mathematics Learning (PMR) approach and the student learning outcome in the set material using the Contextual Learning approach (CTL). Because the student learning outcome in the set material using Realistic Mathematics Learning (PMR) approach better than the student learning outcome in the set material using the Contextual Learning approach (CTL).
\end{abstract}

Keywords: Contextual Learning; Learning Outcomes; Realistic Mathematics Learning.

\section{INTRODUCTION}

The mathematics learning is currently undergoing a paradigm shift from the teachercentered learning to the student-centered learning (Lusiana, Budiyono, \& Sutanto, 2013). The student-centered learning aims to activate the students in the learning process, but there are schools that still implement teacher-centered learning such as in MTsN 33 Jakarta so that the student learning outcomes are not satisfactory. It can be seen from the questionnaire test of all 7th grade students of MTsN 33 Jakarta, about $40 \%$ of students are less interested or do not like learning mathematics, especially on the set material. This result is supported by the results of the students' grade data based on the 2016-2017 school teacher value data with the average results of grades VII students for the set material is still low at 60 with $\mathrm{kkm} 85$.

. Based on the results of interviews with the teacher of the mathematics subjects it was found that the model used in learning was the conventional method (lecture) and the lack of use of teaching tools because the use of teaching tools was considered to be quite expensive. As the result, the teacher finds it difficult to explain what they want to conveys to the students that make the students will tend to be lesactive, creative, and critical in learning (Wirama, Pudjawan, \& Dibia, 2014). The mastery and understanding of students towards mathematical concepts is weak because it is not profound so the participants receive what is conveyed by the teacher without understanding and knowing what the teacher is conveyed. In addition, the knowledge is quickly forgotten by the student and also not able to be applied to everyday life because it makes low learning outcomes of students (Firdaus, Novita \& Khairunnisak, 2014; Septianawati, Budiyono , \& Subanti, 2013) 
It is caused the inappropriate learning strategies to the students, the learning strategy is presented by the teacher is very important. There are various learning strategies that can be used one of them by using the realistic Mathematics Learning approach (PMR) and the Contextual Learning approach (CTL).The PMR approach is one of the approaches to learning mathematics that is oriented towards mathematical experiences and applying mathematics in everyday life (Ardiawan, Budiyono, \& Subanti, 2013).

The various advantages of the PMR approach have been shown from the results of previous research, such as PMR making it easier for the students to understand algebraic concepts (Chang \& Huang, 2014), PMR can improve learning achievement (Zainal, 2017), PMR can improve students' understanding of fractions (Mustikahadi, Suyanto, \& Chamdani, 2015; E. Safitri, Wahyudi, \& Warsiti, 2014), PMR affects student learning outcomes (Hanisah, Hamizi, \& Erlisnawati, 2016; Julita, Marhadi, \& Noviana, 2016; Jumiati, N, \& Zulkifli, 2014; Miftahurahmah, Marhadi, \& Noviana, 2016; Wirama et al., 2014), PMR influences the student problem solving abilities (Krismiati, 2013; Susana \& Zubir, 2014), and PMR can improve mathematical reasoning abilities (Lestari, Prahmana, \& Wijayanti, 2016).

The CTL approach is a holistic learning process and aims to help students to understand the meaning of the teaching material by linking it to the context of their daily lives (personal, social and cultural context), so that students have dynamic and flexible knowledge / skills to actively construct their own understanding (Ariestuti, Darsana, \& Kristiantari, 2014; Permatasari \& Muslim, 2014).

The Previous researchers have used the CTL approach in research. This is because the CTL approach can help in The student problem solving (Camilah, Suharto, \& Indah, 2014), CTL assisted with performance appraisal influences the understanding of the science concept (Dewi \& Rati, 2013), CTL based on local wisdom influences the learning outcomes of IPS (Hermawan , Jampel, \& Widiana, 2013), CTL with concrete material media can improve science learning (Nugraeni, Triyono, \& Budi, 2016), CTL influences economic learning achievement (Suprihatin, Siswandari, \& Sutarno, 2013), CTL with experimental methods can improve the student science learning outcomes (Kurniawati, Suripto, \& Warsiti, 2016), CTL with teaching tools can improve understanding of physics concepts (Faikoh \& Maftukhin, 2013), CTL can improve students' psychomotor abilities (Haloho, 2015), CTL can improve the student ability on writing (Oktarina, 2015), CTL can improve the student science learning outcomes (Daud \& Riau, 2015; Mongan, A, \& Alibasyah, 2015; Samriani, 2016).

The Low student learning outcomes are caused of inappropriate learning strategies. The student learning outcomes are the result of an interaction between learning and teaching. From the teacher's factor the teaching action ends with a learning evaluation process, while from the student learning outcomes is the culmination of the learning process (Rohmaniar, Jalmo, \& Marpaung, 2015). In previous research, many research have used learning models to examine student learning outcomes such as research by (Febri, Achmad, \& Marpaung, 2015) using the TGT model with snake ladder media, (A. Safitri, Achmad, \& Marpaung, 2015) using a model Two Stay Two Stray (TSTS), (Rahmayanti, 2015), uses the CIRC and RME models, (Asmara, 
Ngadino, \& Lestari, 2015) using the Group Investigation (GI) and (Damayanti, 2015) models using the NHT and TPS models.

Based on the description above, the two approaches are equally capable of helping students in understanding learning related to daily life (contextual), especially in the set material that requires many examples related to daily life. As for the novelty of the researcher in this research, the researcher will try to see the differences in The student learning outcomes with the PMR approach and the CTL approach on the Material set.

\section{THE RESEARCH METHODS}

The research method uses of quasi experimental with posttest only control design.Populasi design of this research is all class VII MTsN 33 East Jakarta. Sampling technique was used cluster random sample with class VII-1 as the experimental class 1, VII-2 as the experimental class 2 . The data collection technique using the model documentation and test models. Model documentation used to obtain the primary capability experimental class 1 and experiment 2. While the test models used to obtain data on the study of students classroom experiment 1 and experiment 2.Model tests are used to collect data from the student studying mathematics with multiple choice tests form in 30 question items, each item consists of four multiple choices A, B, C, D. The test was given after fulfilling the validity of question and tested in class VIII-1 to see the level of difficulty and the distinguishing item, as well as reliability testing of each instrument test. Both classes are assumed in the given treatment. The design can be described as follows.

Table 1. The Experiment Research Design

\begin{tabular}{lcc}
\multicolumn{1}{c}{ Class } & Treatment & $\begin{array}{c}\text { Final Test } \\
\text { (Post Test) }\end{array}$ \\
\hline Experimental Class 1 & $X_{1}$ & $O_{1}$ \\
\hline Experimental Class 2 & $X_{2}$ & $O_{2}$ \\
\hline
\end{tabular}

Description:

$X_{1} \quad=$ The Treatment using PMR Approach

$X_{2}=$ The Treatment using CTL Approach

$O_{1}=O_{2}=$ Final Test (posttest) Experimental 1 and Experimental class 2

Before testing the hypothesis, a prerequisite analysis test is performed on the student primary ability of each class is taken from the odd semester UAS grade for balance testing with a significance level of 0.05 . Test prerequisite analysis is the normality test using Lillifors test, homogeneity test. If the test results are normally distributed and come from the similiar variance area, the Statistical Hypothesis is tested using the t-test. The Assumptions for normality testing are:

$H_{0}$ : The Data is normally distributed

$H_{1}$ : The Data is not normally distributed

The Criteria Test: If $L_{\text {count }}<L_{\text {table }}$ then $H_{0}$ Accepted, so that the both data are normally distributed. 
The Assumptions for homogeneity testing are:

$H_{0}$ : The data is homogeneity

$H_{1}$ : The data is not homogeneity.

The Criteria Test : If $F_{\text {count }}<F_{\text {table }}$ then $H_{0}$ accepted, so that the both data are homogeneity.

The comparison of hypotheses is based on the formulation of the right-hand test hypothesis. If $T_{\text {Count }} \leq T_{\text {Table }}$, Then $H_{O}$ Accepted. With the hypothesis is tested :

$H_{O}: \mu_{1} \leq \mu_{2}, \quad H_{1}: \mu_{1}>\mu_{2}$

$\mu_{1}$ : The learning outcomes with the realistic mathematics approach (PMR)

$\mu_{2}$ : The learning outcomes with the contextual approach (CTL)

\section{THE RESULTS OF THE RESEARCH AND THE DISCUSSION}

After the student learning outcomes data are collected from the two experimental classes 1 (PMR approach treatment) and from Experiment 2 class (CTL approach treatment) were taken then obtained:

Table 2. The data description of student learning outcome result

\begin{tabular}{lccccc}
\hline \multicolumn{1}{c}{ Class } & $\mathbf{X}_{\max }$ & $\mathbf{X}_{\min }$ & \multicolumn{3}{c}{ The size of central tendency } \\
\cline { 4 - 6 } & & & $\overline{\boldsymbol{x}}$ & $\mathbf{M e}$ & $\mathbf{M o}$ \\
\hline Exeriment 1 & 95 & 30 & 62,44 & 60 & 60 \\
Experiment 2 & 77 & 30 & 50,19 & 47 & 40 \\
\hline
\end{tabular}

After learning, the experimental class 1 (PMR method treatment) and Experiment 2 class (CTL method treatment) was carried out a final evaluation to find out the learning outcomes of students as data collection of the final evaluation obtained that in the experimental class 1 there were 30 students with essay questions on the ability to understand mathematical concepts obtained the largest grade 95 and the smallest grade 35, middle grade (Me) 60, the most grade obtained by students (Mo) is 60 and the average grade of students is 62.44. Whereas in Experiment 2 class which amounted to 30 students with learning outcomes of students obtained the largest grade of 77 and the smallest grade of 20, the average grade obtained by the student was 50.19, with Median 47 and the grade appeared was 40. Based on It can be concluded that the experimental class 1 student learning outcomes (PMR method treatment) are better than Experiment 2 class (CTL method treatment).

Furthermore, the assumption test analysis is performed by testing the normality of learning outcomes of students in the experimental class 1 with the experimental class score of 62.444 with $\boldsymbol{L}_{\text {Count }}=, \mathbf{0 , 1 1 1 7}$ and $\boldsymbol{L}_{\text {table }}=\mathbf{0 . 1 4 5 4}$. And experimental class 2 is 50.1935 with $\boldsymbol{L}_{\text {count }}=\mathbf{0 , 1 0 1 6}$ and $\boldsymbol{L}_{\text {table }}=\mathbf{0 , 1 5 5 6}$ it shows that $\boldsymbol{L}_{\text {Count }}<\boldsymbol{L}_{\text {table }}$ so that the data can be concluded that it is normally distributed. The following recapitulation results of the calculation of the student learning outcomes in experimental class 1 and experimental class 2 .

Table 3. The Calculation of Normal Tests Result

\begin{tabular}{ccccc} 
Class & Sample Amount & $\boldsymbol{L}_{\text {count }}\left(L_{(\alpha, n)}\right)$ & $\boldsymbol{L}_{\text {table }}$ & Description \\
\hline Experiment 1 & 36 & 0,1117 & 0.1454 & Normal \\
Experiment 2 & 31 & 0,1016 & 0,1556 & Normal \\
\hline
\end{tabular}


Based on the calculation results of the normality test of the mathematics learning outcomes of students. Ability in experimental class 1 and experimental class 2 with a significance level of $\alpha=0.05$, obtained that the value of $L_{\text {Count }}$ of each group is less than $L_{\text {table }}$ so that the null hypothesis of each group is accepted. It can be concluded that the data obtained from each group comes from a population that is normally distributed.

To find out the differences of the two scores have the same or different characters, the $\mathrm{F}$ test is needed. This variance test is comparing the largest variance and the smallest variance. If $F_{\text {count }} \leq F_{\text {table }}\left(\sigma_{1}, \sigma_{2}\right)$ is obtained from the distribution with probability $\frac{1}{2} \alpha$ while the degree of freedom is $\sigma_{1}\left(n_{1}-1\right)$ and $\sigma_{2}\left(n_{2}-2\right)$ each corresponds to the dk numerator and the $\mathrm{dk}$ denominator. The Variance testing results with a significant level of $\alpha=0,05$ can be seen in Table 4.

Table 4 . The results of Test Calculations Similarities Two Varies

\begin{tabular}{cccccc}
\hline Class & Sample Amount & Variants & $\boldsymbol{F}_{\text {count }}$ & $\boldsymbol{F}_{\text {table }}$ & Description \\
\hline Experiment 1 & 30 & 63,454 & 1,204 & 1,810 & Homogeny \\
\hline Experiment 2 & 30 & 218,694 & 1,204 & 1,810 & Homogeny
\end{tabular}

Based on Table 3. The score results of the calculation understanding mathematical concepts ability is obtained $F_{\text {Count }}=1.204$ and $F_{\text {table }}=1.810$. Showing that $F_{\text {count }}<F_{\text {table }}$.It can be concluded that $H 0$ is accepted or the sample comes from a population that has the similar variance. To test differences in mathematical learning outcomes students used the t-test formula, because the data is obtained were normally distributed and had the similar variance grade. The calculation results can be seen in Table 5. Below:

Table 5 . The results of Test Calculations Similarities Two Varies

\begin{tabular}{lccccc}
\hline Class & Sample Amount & Average $(\boldsymbol{x})$ & $\boldsymbol{t}_{\text {tabel }}\left(\boldsymbol{t}_{\boldsymbol{a}, \boldsymbol{d b} \boldsymbol{b}}\right)$ & $t_{\text {count }}$ & Description \\
\hline Experiment 1 & 30 & 62,444 & \multirow{2}{*}{1,668} & \multirow{2}{*}{12,868} & \multirow{2}{*}{$\mathrm{H}_{0}$ Accepted } \\
\hline Experiment 2 & 30 & 50,193 & & & \\
\hline
\end{tabular}

Base on the Table 5. the calculation is obtained $t_{\text {count }}=12,868$ dan $t_{\text {table }}=1,668$ so that is $t_{\text {count }}>t_{\text {table }}$, then $H_{0}$ is rejected. from the average learning outcomes of students can be seen in table 4 is obtained experimental class 1 (the class that received treatment PMR) is obtained a grade of 62.444 while the experimental class 2 (the class that received treatment CTL) is obtained a grade of 50.193, the results of this analysis can be concluded that there is a difference that students' mathematics learning outcomes between experimental class 1 (the class receiving PMR treatment) are better than the experimental class 2 (the treatment class with the CTL model). The results of this study are similar to the results of previous research with the results that the PMR approach is able to help students in the process of contextual learning or link learning in real life besides PMR learning model is able to help the students to understand the ability to the comprehend concepts and make students more creative in learning mathematics (Astuti et al., 2018; Suherman, 2015) and PMR can improve students' mathematics learning outcomes (Hanisah et al., 2016; Julita et al., 2016; Miftahurahmah et al., 2016). 


\section{CONCLUSION AND SUGGESTION}

Based on the theory and supported by the results of the analysis and processing of data and referring to the formulation of the problems that have been described, it can be concluded that: there are differences in learning outcomes of students with the application of PMR approach (realistic mathematics learning) with the application of CTL approaches (contextual teaching and learning). The further results of students' mathematics learning on the set material with the implementation of the PMR approach (learning of realistic mathematics) is better than the learning outcomes of students on the set material with the implementation of the CTL approach (context teaching and learning). Based on the conclusions the researcher suggest that the teacher uses the PMR approach (learning realistic mathematics) to improve student learning outcomes in the set material.

\section{REFERENCES}

Ardiawan, Y., Budiyono, B., \& Subanti, S. (2013). Efektivitas Model Kooperatif Tipe NHT dengan PMR dan Model Kooperatif Tipe GI dengan PMR terhadap Prestasi Belajar Matematika Ditinjau dari Kreativitas Siswa.

Ariestuti, P. D., Darsana, I. W., \& Kristiantari, R. (2014). Penerapan Pendekatan Contextual Teaching And Learning ( CTL ) Untuk Meningkatkan Keaktifan Dan Hasil Belajar IPA Siswa Kelas VI SDN 3 Tonja Tahun Ajaran 2014/2015. Jurnal Mimbar PGSD Universitas Pendidikan Ganesha, 2(1).

Asmara, B. A., Ngadino, \& Lestari, L. (2015). Pengaruh Penerapan Model Pembelajaran Kooperatif Tipe Group Investigation (GI) Terhadap Hasil Belajar IPA Materi Sumber Daya Alam. Jurnal Didaktika Dwija Indria, 3(4), 168-172.

Astuti, R. P. S., Yuanita, P., \& Anggraini, R. D. (2018). Pengaruh Penerapan Pendekatan Pembelajaran Matematika Realistik (PMR) Terhadap Kemampuan Pemecahan Masalah Matematika Siswa Kelas VII SMP Muhammadiyah 1 Pekanbaru. Jurnal Online Mahasiswa (JOM) Bidang Keguruan Dan Ilmu Pendidikan, 5(1), 1-13.

Camilah, D. S., Suharto, \& Indah, A. (2014). Penerapan Pendekatan Contextual Teaching And Learning (Ctl) Untuk Membantu Siswa Mengatasi Kesalahan Dalam Menyelesaikan Soal Cerita Pokok Bahasan Bilangan Bulat Siswa Kelas VII Semester Ganjil SMP Plus Miftahul Arifin Tahun Ajaran 2013/2014. Pancaran Pendidikan, 3(3), 31-40.

Chang, Y. L., \& Huang, Y. I. (2014). A Study of Improving Eighth Graders' Learning Deficiency in Algebra by Applying a Realistic Context Instructional Design. International Education Studies, 7(1), 1-8.

Damayanti, Y. (2015). Eksperimentasi Model Pembelajaran NHT Dan TPS Terhadap Hasil Belajar Matematika Siswa. Ekuivalen, 13(1), 70-75.

Daud, D., \& Riau, U. (2015). Penerapan Pendekatan Contextual Teaching And Learning ( CTL) Untuk Meningkatkan Hasil Belajar IPA Siswa Kelas IV SD Negeri 017 Bagan Punak Meranti Kecamatan Bangko Kabupaten Rokan Hilir. Jurnal Online Mahasiswa (JOM) Bidang Keguruan Dan Ilmu Pendidikan, 2(1), 1-10. 
Dewi, N. R. Y., \& Rati, N. W. (2013). Pengaruh Pendekatan CTL Berbantuan Penilaian Kinerja Terhadap Pemahaman Konsep Ipa Siswa Kelas V SD Negeri 1 Sangsit. Mimbar PGSD, 1.

Febri, Achmad, A., \& Marpaung, R. R. T. (2015). Penggunaan Model TGT Dengan Media Ular Tangga Terhadap Peningkatan Hasil belajar. Jurnal Bioterdidik, 3(2).

Firdaus, Novita, R., \& Khairunnisak, C. (2014). Hasil Belajar Siswa Pada Materi Bidang Datar Dengan Menggunakan Pendekatan CTL Di SMP Muhammadiyah I Banda Aceh. Visipena, $5(2)$.

Haloho, R. C. (2015). Implementasi Pendekatan Contextual Teaching Learning (CTL) Untuk Meningkatkan Kemampuan Psikomotorik Siswa Pada Mata Pelajaran Fisika SMA Negeri 1 Percut Sei Tuan. Elementary Journal School PGSD FIP UNIMED, 3(2), 121-131.

Hanisah, Hamizi, \& Erlisnawati. (2016). Penerapan Pendekatan Pembelajaran Matematika Realistik (PMR) Untuk Meningkatkan Hasil Belajar Matematika Siswa Kelas II A SD Negeri 25 Pekanbaru. Jurnal Online Mahasiswa (JOM) Bidang Keguruan Dan Ilmu Pendidikan, 3(1), 1-12.

Hermawan, I. P. E., Jampel, I. N., \& Widiana, I. W. (2013). Pengaruh Pembelajaran Pendekatan Contextual Teaching and Learning (CTL) Berbasis Kearifan Lokal Terhadap Hasil Belajar Ips Siswa Kelas IV SD. Mimbar PGSD.

Julita, S., Marhadi, H., \& Noviana, E. (2016). Penerapan Pendekatan Pembelajaran Matematika Realistik ( PMR ) Untuk Meningkatkan Hasil Belajar Matematika Siswa Kelas IV SDN 015 Seremban Jaya Kecamatan Rimba Melintang. Jurnal Online Mahasiswa (JOM) Bidang Keguruan Dan Ilmu Pendidikan, 3(1), 1-12.

Jumiati, N, L., \& Zulkifli. (2014). Penerapan Pendekatan Pembelajaran Matematika Realistik ( PMR ) Untuk Meningkatkan Hasil Belajar Matematika Siswa Kelas IV SDN 029 Sungai Agas Kecamatan Kubu. Jurnal Online Mahasiswa (JOM) Bidang Keguruan Dan Ilmu Pendidikan, 1(2), 1-12.

Krismiati, A. (2013). Penerapan Pembelajaran Dengan Pendidikan Matematika Realistik (PMR) Secara Berkelompok Untuk Meningkatkan Kemampuan Pemecahan Masalah Matematis Siswa Di Kelas X SMA. Infinity, 2(2), 123-135.

Kurniawati, A., Suripto, \& Warsiti. (2016). Penerapan Pendekatan CTL Dengan Metode Eksperimen Dalam Peningkatkan Hasil Belajar IPA Tentang Gaya Kelas IV SD Negeri 2 Panjer. Kalam Cendikia Kebumen, 5(4).

Lestari, I., Prahmana, R. C. I., \& Wijayanti, W. (2016). Peningkatan Kemampuan Penalaran Matematis Siswa Menggunakan Pendekatan Pendidikan Matematika Realistik (PMR). Jurnal Inovasi Pendidikan Dasar, 1(2), 45-50.

Lusiana, R., Budiyono, \& Sutanto. (2013). Efektivitas Pendekatan Quantum Learning dan Contextual Teaching and Learning (CTL) Terhadap Prestasi Belajar Matematika Ditinjau Dari Pola Asuh Orang Tua Siswa SMP Di Kabupaten Magetan Tahun Ajaran 2012/2013. Jurnal Pembelajaran Matematika, 1(2), 213-224.

Miftahurahmah, Marhadi, H., \& Noviana, E. (2016). Penerapan Pendekatan Pembelajaran 
Matematika Realistik (PMR) Untuk Meningkatkan Hasil Belajar Matematika Siswa Kelas IV SDN 003 Sungai Manasib Kecamatan Bangko Pusako. Jurnal Online Mahasiswa (JOM) Bidang Keguruan Dan Ilmu Pendidikan, 3(1), 1-16.

Mongan, A. L., A, M. A., \& Alibasyah, L. (2015). Meningkatkan Hasil Belajar Siswa Pada Mata Pelajaran IPA Melalui Pendekatan Contekstual Teaching Learning (CTL) Pada Siswa Kelas IV SDN Santingi. Jurnal Kreatif Tadulako, 4(5), 149-161.

Mustikahadi, V., Suyanto, I., \& Chamdani, M. (2015). Penggunaan Pendekatan Pendidikan Matematika Realistik (PMR) Dalam Peningkatan Pemahaman Pecahan Siswa Kelas III SD Negeri 1 Karangtanjung Tahun Ajaran 2012/2013. Kalam Cendikia PGSD Kebumen, 4(4).

Nugraeni, D. N., Triyono, \& Budi, H. S. (2016). Penerapan Pendekatan CTL Dengan Media Benda Konkret Dalam Peningkatan Pembelajaran IPA Siswa Kelas V SDN Patemon Tahun Ajaran 2012/2013. Kalam Cendikia PGSD Kebumen, 5(3).

Oktarina, M. (2015). Peningkatan Kemampuan Menulis Melalui Pendekatan Contextual Teaching And Learning (CTL). J-Simbol (Bahasa, Sastra, Dan Pembelajarannya), 3(1), $1-12$.

Permatasari, S. W. E., \& Muslim, S. (2014). Implementasi Model Pembelajaran Contextual Teaching and Learning (CTL) Pada Standar Kompetensi Dasar Memasang Instalasi Penerangan Listrik di SMKN 7 Surabaya. Jurnal Pendidikan Teknik Elektro, 3(2), 47-53.

Rahmayanti, F. (2015). Eksperimentasi Model Pembelajaran CIRC Dan RME Terhadap Hasil Belajar Ditinjau Dari Keaktifan Siswa. Ekuivalen, 13(3), 236-240.

Rohmaniar, Jalmo, T., \& Marpaung, R. R. T. (2015). Pengaruh Penggunaan Model Jigsaw Terhadap Aktivitas Dan Hasil Belajar Siswa. Jurnal Bioterdidik, 3(3), 1-13.

Safitri, A., Achmad, A., \& Marpaung, R. R. T. (2015). Pengaruh Model Pembelajaran Two Stay Two Stray ( TSTS ) Terhadap Hasil Belajar Siswa. Jurnal Bioterdidik, 3(2).

Safitri, E., Wahyudi, \& Warsiti. (2014). Penggunaan Pendekatan Pendidikan Matematika Realistik (PMR) Dalam Peningkatan Pembelajaran Matematika Tentang Pecahan Siswa Kelas IV SD. Kalam Cendikia PGSD Kebumen, 3(2).

Samriani. (2016). Penerapan Pendekatan Contextual Teaching And Learning (CTL) dalam Meningkatkan Hasil Belajar Siswa Pada Mata Pelajaran IPA di Kelas IV SDN No 3 Siwalempu. Jurnal Kreatif Tadulako Online, 4(2), 56-74.

Septianawati, D., Budiyono, \& Subanti, S. (2013). Efektivitas Penerapan Metode Diskusi Dengan Pendekatan Matematika Realistik (PMR) Dan Pendekatan Quantum Learning (QL) Ditinjau Dari Tipe Kepribadian Siswa Untuk Meningkatkan Prestasi Belajar Matematika Siswa Kelas VIII SMP Negeri di Kabupaten Lampung Timur. Jurnal Pembelajaran Matematika, 143-152.

Suherman, S. (2015). Kreativitas Siswa Dalam Memecahkan Masalah Matematika Materi Pola Bilangan Dengan Pendekatan Matematika Realistik (PMR). Al-Jabar : Jurnal Pendidikan Matematika, 6(1), 81-90. 
Suprihatin, S., Siswandari, \& Sutarno. (2013). Pengaruh Pembelajaran Ekonomi Dengan pendekatan Contextual Teaching And Learning (CTL) Terhadap Prestasi Belajar Ekonomi Ditinjau Dari Kemampuan Awal Siswa. Jurnal Pendidikan Mandiri, 2(1), 71-88.

Susana, D., \& Zubir, A. (2014). Penerapan Pendekatan Pendidikan Matematika Realistik (PMR) Terhadap Kemampuan Pemecahan Masalah Matematika Siswa SMP Negeri 1 Sungai Penuh. Jurnal Penelitian Universitas Jambi, 17(1), 52-56.

Utari, V. (2012). Peningkatan Kemampuan Pemahaman Konsep Melalui Pendekatan PMR dalam Pokok Bahasan Prisma Dan Limas. Jurnal Pendidikan Matematika, 1(1).

Wirama, M., Pudjawan, K., \& Dibia, I. K. (2014). Pengaruh Pendekatan Matematika Realistik (PMR) Terhadap Hasil Belajar Matematika Kelas V SDN Desa Penglatan Kecamatan Buleleng. Jurnal Mimbar PGSD Universitas Pendidikan Ganesha, 2(1).

Zainal, Z. (2017). Pendekatan Matematika Realistik (PMR) Dalam Meningkatkan Prestasi Belajar Matematika Siswa Kelas V SD Negeri 17 Parepare. Jurnal Publikasi Pendidikan, 7(1), 13-19. 